\title{
Excess primary production, calcification and nutrient fluxes of a patch reef (Tikehau atoll, French Polynesia)
}

\author{
L. Charpy*, C. Charpy-Roubaud, P. Buat \\ ORSTOM, Centre d'Océanologie de Marseille, Traverse de la Batterie des Lions, F-13007 Marseille, France
}

\begin{abstract}
Community metabolism (primary production, respiration and calcification), nutrient budgets, and export of particulate organic matter of a patch reef were investigated in the lagoon of Tikehau atoll (Tuamotu Archipelago, French Polynesia). The pinnacle studied displays strong carbonate dissolution of the top surface layer, estimated to be up to $-37 \mathrm{~g} \mathrm{CaCO}_{3} \mathrm{~m}^{-2} \mathrm{~d}^{-1}$ The net production is negative $\left(-3.2 \mathrm{~g} \mathrm{C} \mathrm{m}^{-2} \mathrm{~d}^{-1}\right)$ and the gross primary production was estimated to be $4.4 \mathrm{~g} \mathrm{C} \mathrm{m}^{-2} \mathrm{~d}^{-1}$ So the lagoonal pinnacle appears to be a sink for particulate organic matter, which is trapped by the reef frame, and a source of nitrate for downstream lagoonal waters.
\end{abstract}

KEY WORDS: Atoll POM Sedimentation - Coral reefs - Calcification · Production - Nutrients

\section{INTRODUCTION}

Patch reefs are a common feature of tropical lagoons and can contribute significantly to the total lagoonal productivity. Plant and animal biomass on patch reefs is high compared to bottom sediments and most lagoonal resources (pearl oysters and fish) are located close to the pinnacles. There are approximately 500 coral reef pinnacles in the lagoon of Tikehau atoll (Tuamotu Archipelago, French Polynesia), which cover nearly $1 \mathrm{~km}^{2}$, i.e. $0.3 \%$, of the lagoon area. Most of them rise from the floor of the lagoon to the surface, but a minor proportion is completely submerged in deep water.

The high animal and plant biomass observed close to the pinnacles can be explained by the presence of favorable substrata for marine plants and refuges for the marine fauna, but also by the important organic production of the pinnacle community. The persistence or disappearance of pinnacles is the result of competition between erosion by wave action and bioerosion and bioaccretion (Hutchings 1986, Sammarco 1996).

The net primary production of coral reef communities can be estimated by measuring net $\mathrm{O}_{2}$ or $\mathrm{CO}_{2}$

•E-mail: charpy@orstom.fr production or export of organic matter from the reef community to surrounding waters (Kinsey 1983, 1985, Hatcher 1990, Crossland et al. 1991, Barnes \& Lazar 1993). Changes in $\mathrm{O}_{2}$ concentration and total alkalinity in the water flowing over coral reef flats are commonly used to estimate reef community production and calcification (see review by Kinsey 1985). If the pinnacle net production was positive, export of particulate organic matter (POM) would be observed and sedimentation of POM would be higher close to pinnacles than at distant sites. In addition, a high positive net production requires elevated uptake of inorganic nutrients, and their concentrations would be lower on the leeward side of the patch reef than on the windward side.

In this paper, we calculate the production of a reference patch reef using $\mathrm{O}_{2}$, total alkalinity, POM and nutrient budgets from the windward and the leeward reef sides. We also try to estimate the export of particulate matter from pinnacles by measuring the particulate matter deposition rate around a pinnacle.

We seek to answer the following questions: (1) What are the excess community production and net calcification of lagoon pinnacles? and (2) Are patch reefs a source or a sink for major nutrients? 


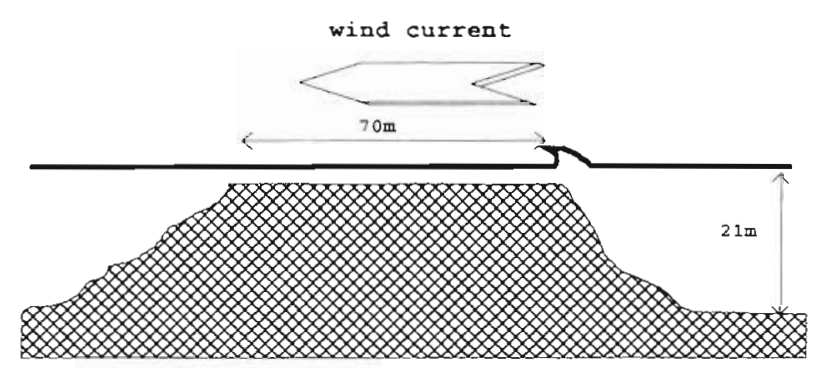

Fig. 1 Schematic representation of reference pinnacle (Tikehau atoll, Tuamotu Archipelago, French Polynesia) investigated in this study

\section{MATERIAL AND METHODS}

Study site. The patch reef chosen was a previously studied patch reef located in the southern part of Tikehau lagoon $\left(15.09^{\circ} \mathrm{S}, 148.24^{\circ} \mathrm{W}\right)$. Bioerosion of this pinnacle was first studied in 1982 by Peyrot-Clausade (1984), and community metabolism of an enclosed community of this pinnacle was investigated in 1989 by Charpy \& Harmelin-Vivien (1992). This patch reef was also chosen for a 5 yr experiment to study bioerosion and accretion (Peyrot-Clausade et al. 1995a, b, Le Bris et al. 1998). It is almost circular with a near surface diameter of $70 \mathrm{~m}$. It rises from the floor of the lagoon (21 $\mathrm{m}$ depth) to within $0.5 \mathrm{~m}$ of the lagoon surface (Fig. 1).

The upper zone ( 0 to $2 \mathrm{~m}$ ) of the pinnacle is colonized by algae (Halimeda, Pocockiella, Caulerpa, Liagora ceranoides, algal turfs). Corals on the windward side are mainly colonies of Porites lobata and Millepora platyphylla whereas the leeward side is mainly colonized by Acropora variabilis, Acropora hyacinthus and Acropora hemprichii. At mid depth (2 to $6 \mathrm{~m}$ ), algae (Halimeda, Caulerpa) compete for space with corals (Montipora, Astropora, Psammocora, Porites, Platygyra, Pavona). The lower zone (6 to $15 \mathrm{~m}$ ) is occupied by patches of the corals Montipora verrucosa, Stylocoeniella, Platygyra daedalea, Acropora formosa, Stylophora pistillata and Favia favus, growing on a detrital or sandy gentle slope (Faure \& Laboute 1984, Harmelin-Vivien 1985). Bioeroders were dominated by mobile cryptofauna, $40 \%$ of which were mollusks (Peyrot-Clausade 1994).

Sampling. Thirty budgets of oxygen, total alkalinity, nutrient and POM were taken in January 1991 and March 1992 from the reference pinnacle. Sampling was conducted at $4 \mathrm{~h}$ intervals during the day and night for a total of five $24 \mathrm{~h}$ periods. Water samples were collected with acid-cleaned Niskin bottles at $0.5 \mathrm{~m}$ depth on the windward side and at $0.5,1.5$ and $2.5 \mathrm{~m}$ depth on the leeward side of the reference pinnacle. Samples were kept in darkness pending analy- sis. Current speed was estimated by measuring the time needed for a neutrally buoyant drifting device to cover the $70 \mathrm{~m}$ of the pinnacle.

Nutrient concentrations $\left(\mathrm{NO}_{2}, \mathrm{NO}_{3}, \mathrm{NH}_{4}, \mathrm{PO}_{4}, \mathrm{SiO}_{2}\right)$, dissolved organic nitrogen (DON) and phosphorus (DOP), total alkalinity (TA), dissolved $\mathrm{O}_{2}$ concentration, particulate organic carbon (POC), nitrogen (PON) and phosphorus (POP), chlorophyll a (chl a), phaeophytin (Pha) and adenosine triphosphate (ATP) were measured in the water column.

Analytical methods. Dissolved inorganic nutrient $\left(\mathrm{NH}_{4}, \mathrm{NO}_{2}, \mathrm{NO}_{3}, \mathrm{SiO}_{2}, \mathrm{PO}_{4}\right)$ concentrations were determined within $1 \mathrm{~h}$ of sampling in the laboratory using the standard techniques described by Strickland \& Parsons (1972). DON and DOP were determined after UV oxidation in the presence of $\mathrm{H}_{2} \mathrm{O}_{2}$ (Strickland \& Parsons 1972). Oxygen was determined using the Winkler procedure.

TA determinations were performed on acidified seawater samples using the method of Perez \& Fraga (1987). The standard error given by the authors is $\pm 0.003 \mathrm{mEq} \mathrm{l^{-1 }}$. Total alkalinity data were not corrected for changes in nutrient concentration (Chisholm \& Gattuso 1991). The $\mathrm{pH}$ was determined at room temperature $\left(22^{\circ} \mathrm{C}\right)$ on submicrosamples $(500 \mu l)$ using an Ingold microelectrode and Hansson's calibration method described by Almgren et al. (1975) as reported in Charpy-Roubaud et al. (1996).

For chemical analyses of POM, $500 \mathrm{ml}$ of seawater was filtered through a $25 \mathrm{~mm}$ diameter Whatman GF/F filter (precombusted for $4 \mathrm{~h}$ at $450^{\circ} \mathrm{C}$ and precleaned with $1 . \mathrm{N} \mathrm{HCl}$ ). POC and PON concentrations were determined after rinsing the filter with $20 \mathrm{ml}$ of $\mathrm{HCl}$ (0.1 N) with a CHN analyzer (Gordon \& Sutcliffe 1973). POP was oxidized with persulfate at $110^{\circ} \mathrm{C}$ for $1.5 \mathrm{~h}$ (Menzel \& Corwin 1965), and phosphate concentrations were subsequently analyzed by spectrophotometry (Strickland \& Parsons 1972).

Chlorophyll content was measured in $250 \mathrm{ml}$ seawater samples filtered through a GF/F filter. Pressure heads during fractionation never exceeded $0.004 \mathrm{~atm}$. Fluorescence was measured before and after acidification with $50 \mu \mathrm{l}$ of $1 \mathrm{~N} \mathrm{HCl}$ (Yentsch \& Menzel 1963). The fluorometer was previously calibrated using Sigma chl a standard.

For ATP analysis, 250 to $500 \mathrm{ml}$ of seawater was filtered through a Millipore $0.45 \mu \mathrm{m}$ filter. ATP extraction was performed immediately in $5 \mathrm{ml}$ of boiling Tris $(0.02 \mathrm{M}, \mathrm{pH}=7.85)$; ATP extracts were frozen at $-20^{\circ} \mathrm{C}$ pending analysis, which occurred no later than $15 \mathrm{~d}$ after sampling. ATP concentrations were measured using the method described by Holm-Hansen \& Booth (1966), with a LKB Luminometer and luciferine-luciferase preparations from Sigma (FLE 50). 
Flux calculation. Fluxes ( $\left.\mathrm{mol} \mathrm{m}^{-2} \mathrm{~h}^{-1}\right)$ from the reef pinnacle were calculated using (Marsh \& Smith 1978):

$$
\text { Flux }=\frac{V_{\mathrm{t}} \times \Delta C}{d}
$$

with $V_{\mathrm{t}}\left(\mathrm{m}^{2} \mathrm{~h}^{-1}\right)=$ volume transport per unit width of reef perpendicular to the direction of water flow ( $V_{t}$ is the product of the current velocity and water depth; Maragos 1978); $C$ (mol, Eq or $\mathrm{mg} \mathrm{m}^{-3}$ ) = change in $\mathrm{O}_{2}, \mathrm{TA}$, nutrient or POM concentration between the upstream and downstream sides; and $d$ $(\mathrm{m})=$ distance between upstream and downstream sides.

The diffusion correction was applied to oxygen budgets according to the principles outlined by Odum \& Hoskin (1958). No diffusion correction was applied to $\mathrm{CO}_{2}$ budgets.

Estimation of the community net calcification and production. For each mole of $\mathrm{CaCO}_{3}$ precipitated, TA is lowered by 2 equivalents; the converse is true for $\mathrm{CaCO}_{3}$ dissolution (Smith \& Kinsey 1978). Therefore, community net calcification ( $\mathrm{mg} \mathrm{CaCO}_{3} \mathrm{~h}^{-1}$ ) can be calculated by:

$$
\frac{\Delta \mathrm{CaCO}_{3}}{\mathrm{~d} t}=\frac{\Delta \mathrm{TA}}{\mathrm{d} t} \times 50
$$

Changes in $\mathrm{CO}_{2}$ due to photosynthesis were calculated as the difference between the total $\mathrm{CO}_{2}$ change observed and the $\mathrm{CO}_{2}$ change attributable to calcification (see Smith \& Kinsey 1978).

Trapping rate (TR). Thirty-six measurements of trapping rate of particulate matter were performed in 3 transects oriented as a function of the dominant wind (E-NE) and centered on the reference pinnacle (Fig. 2). Sediment traps were deployed at 2, 6 and $14 \mathrm{~m}$ depth at the 6 stations located $200 \mathrm{~m}$ from the pinnacle (Stns L3, W3, L6, W6, L9, W9), at 2 and $6 \mathrm{~m}$ depth at the 6 stations located $100 \mathrm{~m}$ from the pinnacle (Stns L2, W2, L5, W5, L8, W8), and at $2 \mathrm{~m}$ depth at the 6 stations located $10 \mathrm{~m}$ from the edge of the pinnacle (Stns L1, W1, L4, W4, L7, W7). Additionally, 4 measurements of trapping rate were performed at the ATOLL program. reference station (Stn FA), located $2 \mathrm{~km}$ away from any pinnacle (Charpy \& Charpy-Roubaud 1991), at 2, 6, 14, and $23 \mathrm{~m}$ depth. The sediment traps used in this study consisted of a 9.5 l PVC jar with a trapping surface of $0.014 \mathrm{~m}^{2}$. The ratio of height to width of the jar was 4.9:1. No poisoning was done. The jar was mounted on an anchored nylon rope, and supported by a subsurface float $0.5 \mathrm{~m}$ below the surface. Material was collected for $24 \mathrm{~h}$. Water samples were also collected with a Niskin bottle close to the sediment trap at the beginning of the experiment. Seston was resuspended by magnetic stirring (Charpy \& Charpy-Roubaud 1991) and split into 4 aliquots of $500 \mathrm{ml}$ for duplicate analysis

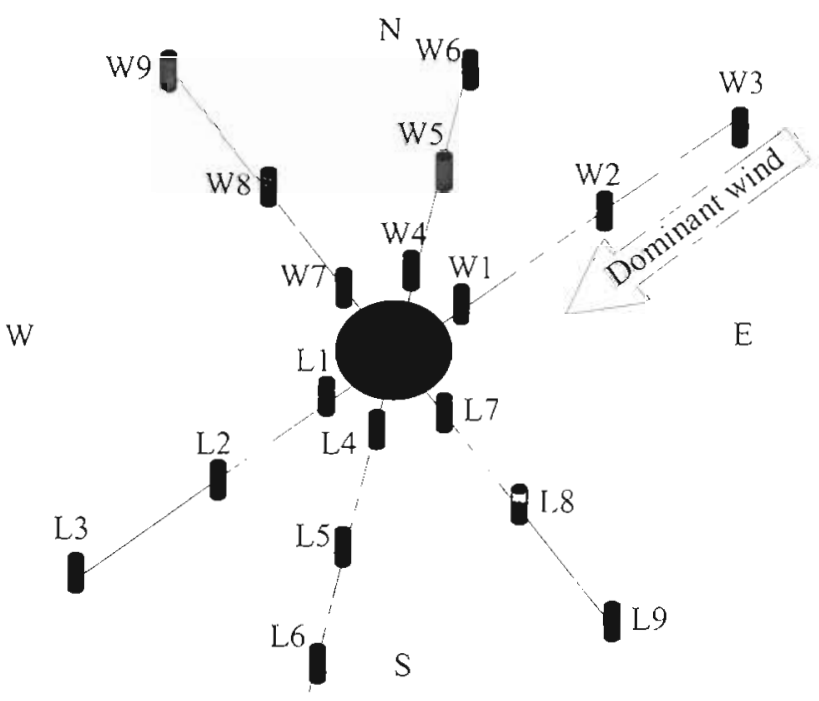

Fig. 2. Map of sediment trap transects centered on the pinnacle

of POC and PON and 2 aliquots of $200 \mathrm{ml}$ for pigment concentrations analysis.

The trapping rate ( $\mathrm{mg}$ POM m $\mathrm{m}^{-2} \mathrm{~d}^{-1}$ ) was calculated using:

$$
\mathrm{TR}=\frac{V \times\left(C_{T}-C_{W}\right)}{\mathrm{d} t \times S}
$$

where $C_{\mathrm{T}}=\mathrm{POM}$ concentration in the trap $\left(\mathrm{mg} \mathrm{m}^{-3}\right)$; $C_{W}=$ POM concentration in the water close to the sediment trap; $V=$ trap volume $\left(\mathrm{m}^{3}\right) ; \mathrm{d} t=$ time interval; $S=$ surface area of the trap that is able to collect material $\left(\mathrm{m}^{2}\right)$.

Terms relevant to coral reei productivity. We use the terms relevant to coral reef productivity presented and discussed by Kinsey (1983, 1985), Hatcher (1990) and Crossland et al. (1991): community gross primary production $\left(P_{g}\right)$, an estimate of carbon fixation by all photosynthetic organisms in the reef; community respiration $(R)$, an estimate of carbon release by decomposition and respiration processes within the community; excess production $(E)$, an estimate of the net community production of organic matter over a $24 \mathrm{~h}$ period. Averages are given with the standard error.

\section{RESULTS}

The average current speed above the reef pinnacle was $6.2 \pm 0.3 \mathrm{~m} \mathrm{~s}^{-1}(\mathrm{n}=30)$.

\section{Community production and net calcification}

Changes in oxygen concentration between the windward and leeward parts of the patch reef varied 


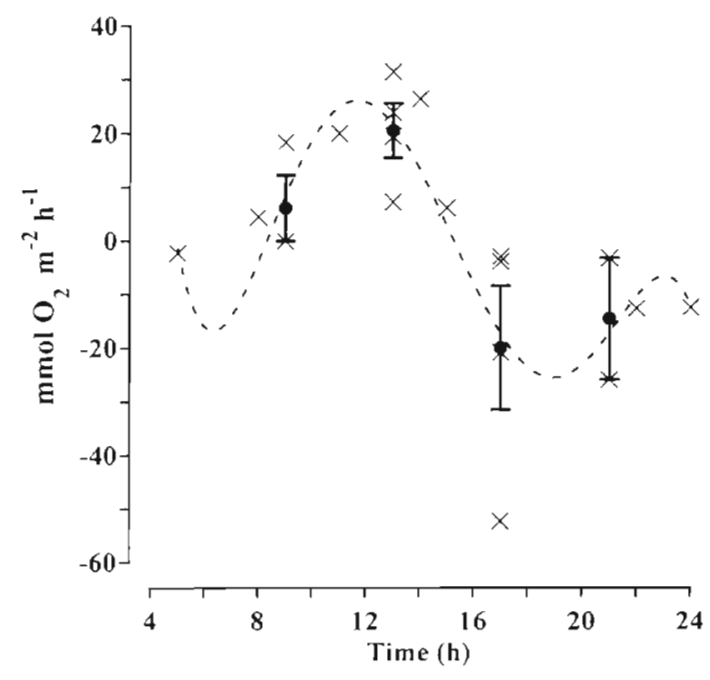

Fig. 3. Net oxygen production flux for the reference pinnacle. (-) Average \pm SD for times with more than one value

between 0 and $14 \%$. The net oxygen production (Fig. 3) varied between -53 and $+31 \mathrm{mmol} \mathrm{O} \mathrm{m}^{-2} \mathrm{~h}^{-1}$ and was significantly different during the day than during the night $(F$-ratio $=23.1, p=0.0001)$. The average nighttime respiration rate was $-15 \pm 5(n=9)$ $\mathrm{mmol} \mathrm{O}_{2} \mathrm{~m}^{-2} \mathrm{~h}^{-1}$ and the average net oxygen production measured during the day was $+14 \pm 3(\mathrm{n}=11)$ mmol $\mathrm{O}_{2} \mathrm{~m}^{-2} \mathrm{~h}^{-1}$ (Table 1 ). The net daily oxygen production was $(+14 \times 12)+(-15 \times 12)=-10 \mathrm{mmol} \mathrm{O} \mathrm{m}^{-2}$ $\mathrm{d}^{-1}$ and the gross daily $\mathrm{O}_{2}$ production was $350 \mathrm{mmol}$ $\mathrm{O}_{2} \mathrm{~m}^{-2} \mathrm{~d}^{-1}$.

Changes in TA between the windward and leeward parts of the patch reef varied between 0.1 and $3 \%$. Net TA changes varied between -200 and $+200 \mathrm{mEq} \mathrm{m}^{-2}$ $\mathrm{h}^{-1}$ (Fig. 4) and was significantly different during the day than during the night ( $F$-ratio $=14.6, \mathrm{p}=0.002)$. Using Eq. (2), we calculated a calcification rate of $+0.59 \mathrm{~g} \mathrm{CaCO}_{3} \mathrm{~m}^{-2} \mathrm{~h}^{-1}$ during daylight and a carbonate dissolution rate of $-3.64 \mathrm{~g} \mathrm{CaCO}_{3} \mathrm{~m}^{-2} \mathrm{~h}^{-1}$ during the night (Table 1). Over a full $24 \mathrm{~h}$ period, the top surface layer of the pinnacle showed a net carbonate dis-

Table 1. Average $( \pm \mathrm{SE})$ net $\mathrm{O}_{2}$ production $\left(\mathrm{mmol} \mathrm{m} \mathrm{m}^{-2} \mathrm{~h}^{-1}\right)$, DIC changes (mmol $\mathrm{m}^{-2} \mathrm{~h}^{-1}$ ) and total alkalinity (TA) changes $\left(\mathrm{mEq} \mathrm{m}^{-2} \mathrm{~h}^{-1}\right)$ between the windward and leeward sides of the reference pinnacle. n: number of samples

\begin{tabular}{|lccc|}
\hline & $\mathrm{O}_{2}$ & $\mathrm{DIC}$ & TA \\
\hline Night & $-15 \pm 5$ & $-63 \pm 35$ & $-73 \pm 40$ \\
17:00 to 05.00h & $\mathrm{n}=9$ & $\mathrm{n}=9$ & $\mathrm{n}=9$ \\
Daylight & $+14 \pm 3$ & $+10 \pm 9$ & $+12 \pm 11$ \\
05:00 to $17: 00 \mathrm{~h}$ & $\mathrm{n}=11$ & $\mathrm{n}=9$ & $\mathrm{n}=9$ \\
\hline
\end{tabular}

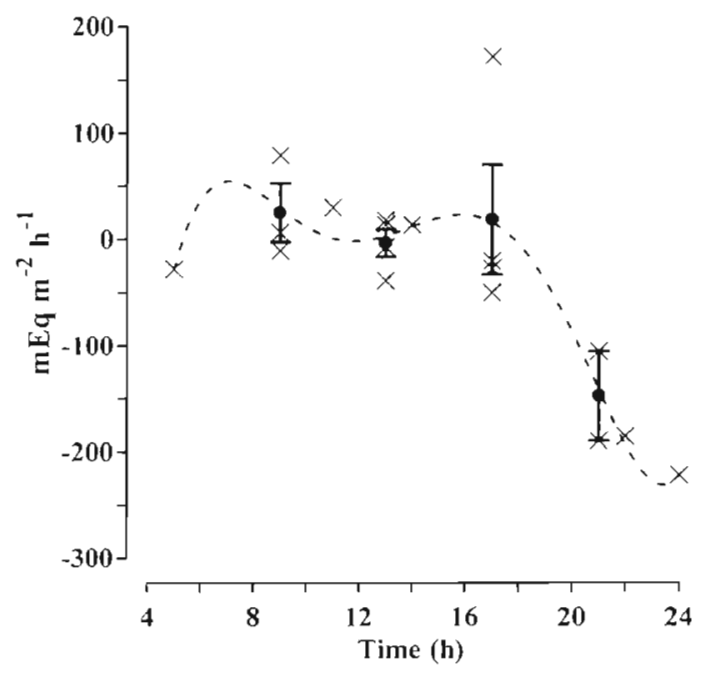

Fig. 4. Net TA changes for the reference pinnacle. (O) Average $\pm \mathrm{SD}$ for times with more than one value

solution rate of $(+0.59 \times 12)+(-3.64 \times 12)=-37 \mathrm{~g}$ $\mathrm{CaCO}_{3} \mathrm{~m}^{-2} \mathrm{~d}^{-1}$.

The net production calculated according to Smith \& Kinsey (1978) was +4 mmol $\mathrm{CO}_{2} \mathrm{~m}^{-2} \mathrm{~h}^{-1}$ during the daylight and $-26 \mathrm{mmol} \mathrm{CO}_{2} \mathrm{~m}^{-2} \mathrm{~h}^{-1}$ during the night. Over a $24 \mathrm{~h}$ period, the excess production $(E)$ was $(+4 \times$ 12) $+(-26 \times 12)=-260 \mathrm{mmol} \mathrm{CO}_{2} \mathrm{~m}^{-2} \mathrm{~d}^{-1}$ and the community gross photosynthesis $\left(P_{\mathrm{g}}\right)$ was $370 \mathrm{mmol}$ $\mathrm{CO}_{2} \mathrm{~m}^{-2} \mathrm{~d}^{-1}$ equivalent to -3.2 and $4.4 \mathrm{~g} \mathrm{C} \mathrm{m}^{-2} \mathrm{~d}^{-1}$.

\section{Nutrient budgets}

Mean nutrient concentrations observed around the reference pinnacle and nutrient budgets between the windward and leeward parts of the pinnacle are summarized in Table 2. $\mathrm{NO}_{3}$ and $\mathrm{NO}_{2}$ concentrations were significantly higher leeward than windward $(p=0.001$ and 0.008 , and $\mathrm{NH}_{4}$ concentration was significantly lower leeward than windward $(p=0.026)$. Since all $p$ values of the $F$-tests were greater than 0.05 , there was no statistically significant difference between the mean net nutrient fluxes from one level of time to another at the $95 \%$ confidence level. Therefore, we averaged these fluxes. $\mathrm{NO}_{2}$ and $\mathrm{NO}_{3}$ fluxes were positive, other nutrient fluxes were negative or close to zero $\left(\mathrm{PO}_{4}\right)$.

\section{POM budgets}

POM concentration on the windward side of the patch reef was significantly correlated with POM conCentrations at the leeward part $(R=0.75, p=0.0003$ for $\mathrm{POC} ; \mathrm{R}=0.96, \mathrm{p}=0.0000$ for $\mathrm{PON}$; and $\mathrm{R}=0.69$, 
Table 2. Average $( \pm \mathrm{SE}$ ) nutrient concentrations $(\mu \mathrm{M})$ on the windward (WW) and leeward (LW) sides of the reference pinnacle. ANOVA results for nutrient budgets by time and average net nutrient fluxes $\left(\mathrm{mmol} \mathrm{m}^{-2} \mathrm{~h}^{-1}\right.$ ) between WW and LW. $\mathrm{n}$ : number of samples

\begin{tabular}{|cccccccc|}
\hline & $\mathrm{PO}_{4}$ & $\mathrm{NO}_{2}$ & $\mathrm{NO}_{3}$ & $\mathrm{NH}_{4}$ & $\mathrm{SiO}_{2}$ & $\mathrm{DON}$ & $\mathrm{DOP}$ \\
\hline $\mathrm{WW}$ & $0.10 \pm 0.01$ & $0.01 \pm 0.00$ & $0.02 \pm 0.00$ & $0.48 \pm 0.04$ & $0.74 \pm 0.08$ & $0.83 \pm 0.12$ & $0.24 \pm 0.03$ \\
$\mathrm{LW}$ & $0.11 \pm 0.02$ & $0.02 \pm 0.00$ & $0.04 \pm 0.01$ & $0.38 \pm 0.03$ & $0.74 \pm 0.08$ & $0.95 \pm 0.16$ & $0.24 \pm 0.03$ \\
$\mathrm{~F}$-ratio & 1.69 & 2.26 & 0.84 & 0.39 & 1.82 & 0.87 & 1.03 \\
$\mathrm{p}$ & 0.15 & 0.06 & 0.61 & 0.95 & 0.13 & 0.59 & 0.46 \\
$\mathrm{Flux}$ & $+0.00 \pm 0.03$ & $+0.02 \pm 0.00$ & $+0.09 \pm 0.02$ & $-0.79 \pm 0.16$ & $-0.6 \pm 0.2$ & $-1.4 \pm 0.6$ & $-0.14 \pm 0.06$ \\
$\mathrm{n}$ & 29 & 30 & 30 & 29 & 29 & 29 & 29 \\
& & & & & & & \\
\hline
\end{tabular}

Table 3. Average ( $(\mathrm{SE})$ POM concentrations $\left(\mathrm{mg} \mathrm{m}^{-3}\right)$ on the windward (WW) and leeward (LW) sides of the reference pinnacle. ANOVA results for particulate organic matter net fluxes by time and average POM net fluxes (mg m $\mathrm{m}^{-2} \mathrm{~h}^{-1}$ ) between $W W$ and $\mathrm{LW}$. n: number of samples

\begin{tabular}{|lcccccc|}
\hline & POP & POC & PON & Chl a & Pha & ATP \\
\hline WW & $2.2 \pm 0.1$ & $142 \pm 10$ & $29 \pm 3$ & $0.37 \pm 0.03$ & $0.21 \pm 0.02$ & $0.08 \pm 0.01$ \\
LW & $2.0 \pm 0.1$ & $131 \pm 7$ & $27 \pm 3$ & $0.36 \pm 0.04$ & $0.21 \pm 0.01$ & $0.10 \pm 0.01$ \\
F-ratio & 0.32 & 1.14 & 0.64 & 2.40 & 1.10 & 0.52 \\
p & 0.95 & 0.42 & 0.74 & 0.12 & 0.45 & 0.80 \\
Flux & $-0.93 \pm 0.26$ & $-26 \pm 15$ & $-3.8 \pm 2.0$ & $+0.07 \pm 0.16$ & $+0.02 \pm 0.11$ & $+0.02 \pm 0.05$ \\
n & 19 & 19 & 19 & 18 & 18 & 13 \\
\hline
\end{tabular}

$p=0.0010$ for POP). POM concentration on the windward side of the patch reef was not significantly different from the POM concentration at the leeward side except for the POP concentration, which was significantly higher at the windward than at the leeward side $(\mathrm{p}=0.024)$. POP, POC, PON, chl a, Pha and ATP budgets varied between -4.1 and $+0.6,-115$ and $+142,-15$ and $+22,-0.8$ and $+1.8,-1.2$ and +1.0 , and -0.3 and $+0.4 \mathrm{mg} \mathrm{m}^{-2} \mathrm{~h}^{-1}$, respectively (Table 3 ). Since all the $\mathrm{p}$-values of the $F$-tests were greater than 0.05, there was no statistically significant difference between the mean net POM fluxes from one level of time to another at the $95 \%$ confidence level. Therefore, we calculated the average of these budgets using all data (Table 3). POC, PON and POP fluxes were negative and chlorophyll, phaeophytin and ATP fluxes were positive.

\section{Sedimentation rates}

The results of the 44 measurements of particulate matter (PM) trapping rate are shown in Fig. 5. Since all the p-values of the $F$-tests were greater than 0.05 (Table 4), there was no statistically significant difference between the mean net PM sedimentation rates from one level of distance from the pinnacle to another at the $95 \%$ confidence level. Average ( $\pm \mathrm{SE}$ ) sedimentation rates were $0.52 \pm 0.04 \mathrm{mg}$ chl $a \mathrm{~m}^{-2} \mathrm{~d}^{-1}, 0.02 \pm$ $0.11 \mathrm{mg}$ Pha $\mathrm{m}^{-2} \mathrm{~d}^{-1}, 155 \pm 11 \mathrm{mg} \mathrm{POC} \mathrm{m}^{-2} \mathrm{~d}^{-1}, 26 \pm$
$2 \mathrm{mg}$ PON m $\mathrm{m}^{-2} \mathrm{~d}^{-1}, 5.8 \pm 0.3 \mathrm{mg}$ POP $\mathrm{m}^{-2} \mathrm{~d}^{-1}, 819 \pm$ $51 \mathrm{mg} P O M \mathrm{~m}^{-2} \mathrm{~d}^{-1}$, and $6120 \pm 400 \mathrm{mg} \mathrm{PM} \mathrm{m}^{-2} \mathrm{~d}^{-1}$. The average $C: N, C: P$ and $N: P$ ratios were $6.1 \pm 0.2$, $30.2 \pm 2.5$ and $5.1 \pm 0.4$, respectively. POC represented on average $20 \pm 2 \%$ of the POM, and POM represented $14 \pm 1 \%$ of the suspended matter. The sedimentation rate increased with depth at stations located far from the pinnacle. There was no evidence of a significant influence of the pinnacle on sedimentation rate during the period of study.

\section{DISCUSSION}

\section{Community net calcification}

We have to take into account the small size of the patch reef $(70 \mathrm{~m})$. Indeed, TA changes between the windward and the leeward side of the patch reef were very small, typically less than 1\%. Barnes (1983) and Barnes \& Lazar (1993) consider that, even with a high rate of community calcification, the change in TA over a short distance $(<50 \mathrm{~m})$ is likely to remain within the errors associated with the technique. However, the level of calcification during daylight was largely lower than the high carbonate dissolution during the night. This may reflect the low proportion of living coral on the lagoonal pinnacles. Therefore, the carbonate budget of the natural community of the pinnacle seems to be unbalanced on short time scales (15 d). In the same 


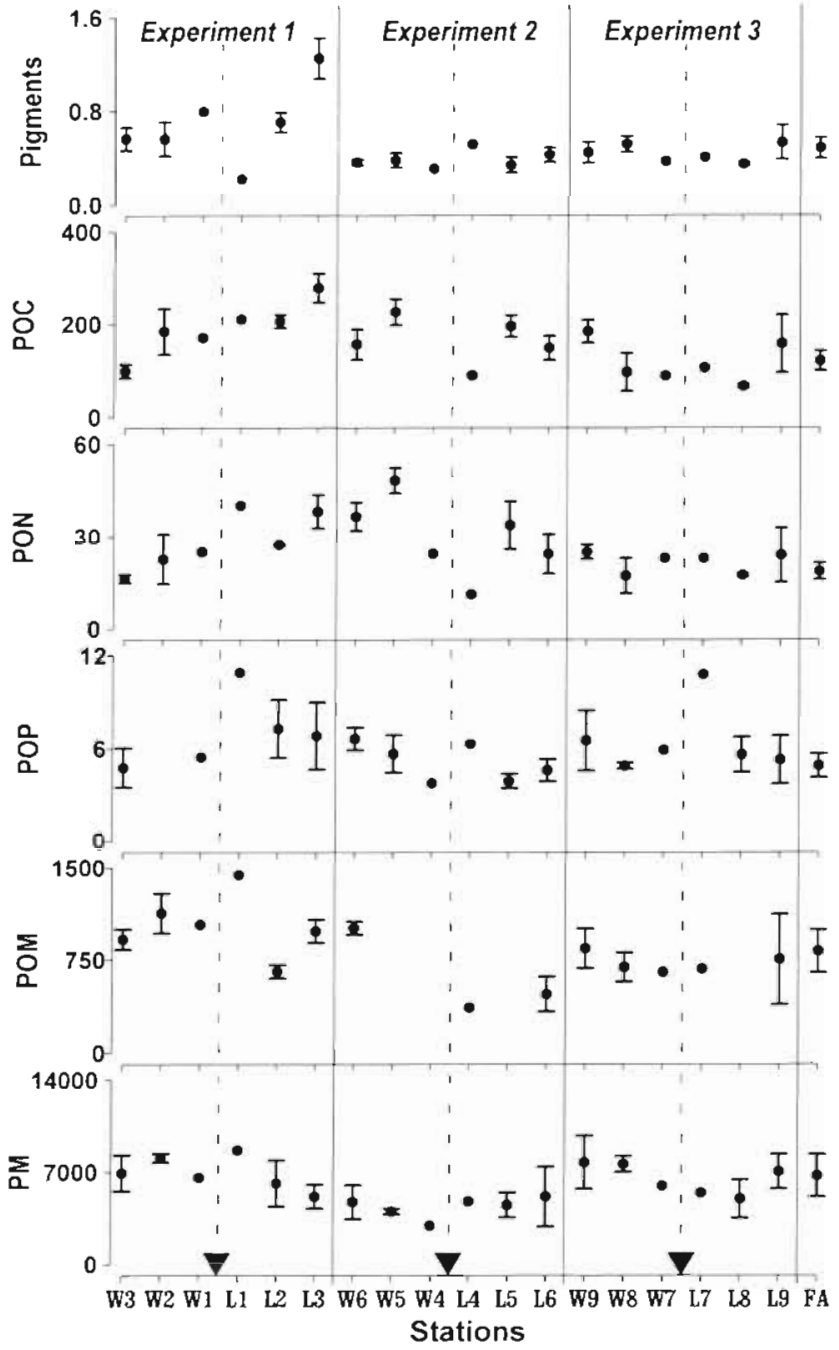

Fig. 5. Average $( \pm S E)$ of sedimentation rates $\left(\mathrm{mg} \mathrm{m}^{-2} \mathrm{~d}^{-1}\right)$ of pigments (chlorophyll + phaeophytin), POC, PON, POP, POM and particulate matter (PM) at 9 stations located leeward (Stns L1 to L9) and windward (Stns W1 to W9) of the reference pinnacle $(\boldsymbol{\nabla})$ and at the Tikehau lagoonal reference station (Stn FA)

patch reef, Peyrot-Clausade et al. (1995a), using experimental coral substrates laid for 6 mo, estimated a rate of internal bioerosion by macroborers of $-0.7 \pm 1.4 \mathrm{~g}$
$\mathrm{CaCO}_{3} \mathrm{~m}^{-2} \mathrm{~d}^{-1}$. After a 2 yr exposure period, the rates of internal and external erosion were $-0.4 \pm 0.7$ and $-2.4 \pm 1.2 \mathrm{~g} \mathrm{CaCO}_{3} \mathrm{~m}^{-2} \mathrm{~d}^{-1}$, respectively (Pari et al. 1998). After a 5 yr exposure period, the rates of internal and external erosion of the experimental substrates increased significantly, reaching, respectively, $-1.4 \pm$ 0.4 and $-24.8 \pm 16.6 \mathrm{~g} \mathrm{CaCO}_{3} \mathrm{~m}^{-2} \mathrm{~d}^{-1}$ (Pari 1998). The increase in internal bioerosion was due to the action of clionid sponges. In the absence of sea urchins, scarids were probably responsible for the external bioerosion (Pari et al. 1998).

The net calcification observed for the Tikehau lagoon pinnacle is very low compared with other published values for Polynesian reef systems (Table 5j. However, most of the studies were carried out on barrier reefs, e.g. the barrier reef of Tiahura at Moorea Island, where water motion conditions are very different from the lagoonal conditions in Tikehau. However, even within the same site, there is a wide range of variation for community structure, partly due to uncertainties related to the standing water technique used by some authors (see Gattuso et al. 1993 for discussion), but also there is some evidence of large seasonal changes in community metabolism (Payri 1987). In the Great Barrier Reef, Sammarco \& Risk (1990) found that internal bioerosion decreased significantly with distance offshore, across the continental shelf. Later, in the same area, Risk et al. (1995) confirmed that bioerosion would be higher in inner- and mid-shelf areas than on the outer shelf. These authors consider that the low level of bioerosion on the outer shelf versus in the inner- and mid-shelf areas may be partially due to lower levels of productivity and lower concentrations of terrestrially derived organic matter. However, there is no terrestrial effect on atoll lagoons

The high temperature of lagoonal waters in January $\left(>30^{\circ} \mathrm{C}\right)$ could be responsible for the high level of carbonate dissolution observed on the coral reef pinnacle. Indeed, high bioerosion rates were also observed after an El Niño warming event in the east Pacific Reefs $\left(-27 \mathrm{~g} \mathrm{CaCO}_{3} \mathrm{~m}^{-2} \mathrm{~d}^{-1}\right.$; Scott et al. 1988), in the Galapagos Islands $\left(-70 \pm 7 \mathrm{~g} \mathrm{CaCO}_{3} \mathrm{~m}^{-2} \mathrm{~d}^{-1}\right.$; Reaka-Kudla et al. 1996) and at Uva Island, Panama (-13 to $-37 \mathrm{~g}$ $\mathrm{CaCO}_{3} \mathrm{~m}^{-2} \mathrm{~d}^{-1}$; Eakin 1996).

Table 4. ANOVA results for particulate matter (PM) sedimentation rate (SR) by distance to the pinnacle and average $( \pm \mathrm{SE}) \mathrm{SR}$ ( $\mathrm{mg} \mathrm{m} \mathrm{m}^{-2} \mathrm{~d}^{-1}$ ). n: number of samples

\begin{tabular}{|lccccccc|}
\hline & POP & POC & PON & Chl $a$ & Pha & POM & PM. \\
\hline F-ratio & 1.71 & 0.66 & 0.50 & 1.25 & 1.12 & 1.50 & 0.28 \\
$p$ & 0.15 & 0.68 & 0.81 & 0.31 & 0.37 & 0.21 & 0.94 \\
SR & $5.8 \pm 0.3$ & $155 \pm 11$ & $26 \pm 2$ & $0.52 \pm 0.04$ & $0.02 \pm 0.1 .1$ & $819 \pm 51$ & $6120 \pm 400$ \\
$n$ & 42 & 43 & 43 & 44 & 44 & 4.2 & 43 \\
\hline
\end{tabular}




\section{Community primary production}

There is a large discrepancy between the estimations of patch reef excess production by the $\mathrm{O}_{2}$ and $\mathrm{CO}_{2}$ methods. The greater resolution associated with the $\mathrm{O}_{2}$ technique is probably more adapted for such small reef systems. Assuming that $P Q$ (photosynthetic quotient $)=R Q$ (respiratory quotient $)=1$, the estimates of $P_{\mathrm{g}}$ and $E$ calculated with the $\mathrm{O}_{2}$ technique are 4.2 and $-0.12 \mathrm{~g} \mathrm{C} \mathrm{m}^{-2} \mathrm{~d}^{-1}$, respectively. Community gross production is low compared with the 'standard' range for reef flats ( $7 \pm 1 \mathrm{~g} \mathrm{C} \mathrm{m}^{-2} \mathrm{~d}^{-1}$ ) given by Kinsey (1985) and other published values for Polynesian reef systems (Table 5). However, the environmental conditions of coral reefs in atoll lagoons are very different from conditions of exposed reefs. A possible limitation of patch reef communities by phosphorus can be expected. Indeed, in Tikehau, Charpy-Roubaud et al. (1990) demonstrated that phosphate concentration was significantly lower in the lagoon of Tikehau than in surrounding oceanic waters. Additionally, the lagoonal water motion is very low compared to exposed reef conditions and the water temperature is significantly higher in the lagoon than in surrounding oceanic water during the austral summer (Charpy 1985).

\section{Nutrient and POM export and import from the pinnacle}

Nutrient concentrations in the water column were very low. Nutrient fluxes from pinnacles calculated from the upstream-downstream difference were close to zero. However, significant uptake of $\mathrm{NH}_{4}$ and $\mathrm{SiO}_{2}$ presumably by benthic algae covering dead corals, was measured. Pinnacles exported on average $2 \mathrm{mmol}$ $\mathrm{NO}_{3} \mathrm{~m}^{-2} \mathrm{~d}^{-1}$, probably due to the presence of nitrifying organisms within the pinnacle. Indeed, high concentrations of $\mathrm{NO}_{3}$ in patch reef cavities have been reported by Andrews \& Müller (1983). Nitrogen fixation could explain part of this $\mathrm{NO}_{3}$ export. Indeed, the average nitrogen fixation by limestone surface communities of the reference pinnacle was estimated to be $0.09 \mathrm{mmol} \mathrm{N}_{2} \mathrm{~m}^{-2} \mathrm{~d}^{-1}$ (Charpy-Roubaud et al. 1997), which represents $9 \%$ of the nitrate export. Authors' unpublished data obtained in 4 other patch reefs confirm the export of $\mathrm{NO}_{3}$ and the uptake of $\mathrm{NH}_{4}$ observed on the reference patch reef.

The variability of the POM concentrations appears more related to the time of sampling than to the location of the station. However, most POM fluxes were negative, indicating an uptake of organic matter (Table 3). The chlorophyllian particles exported from the patch reef are probably reef epiphytes. Most of the organic matter produced by pinnacle communities is

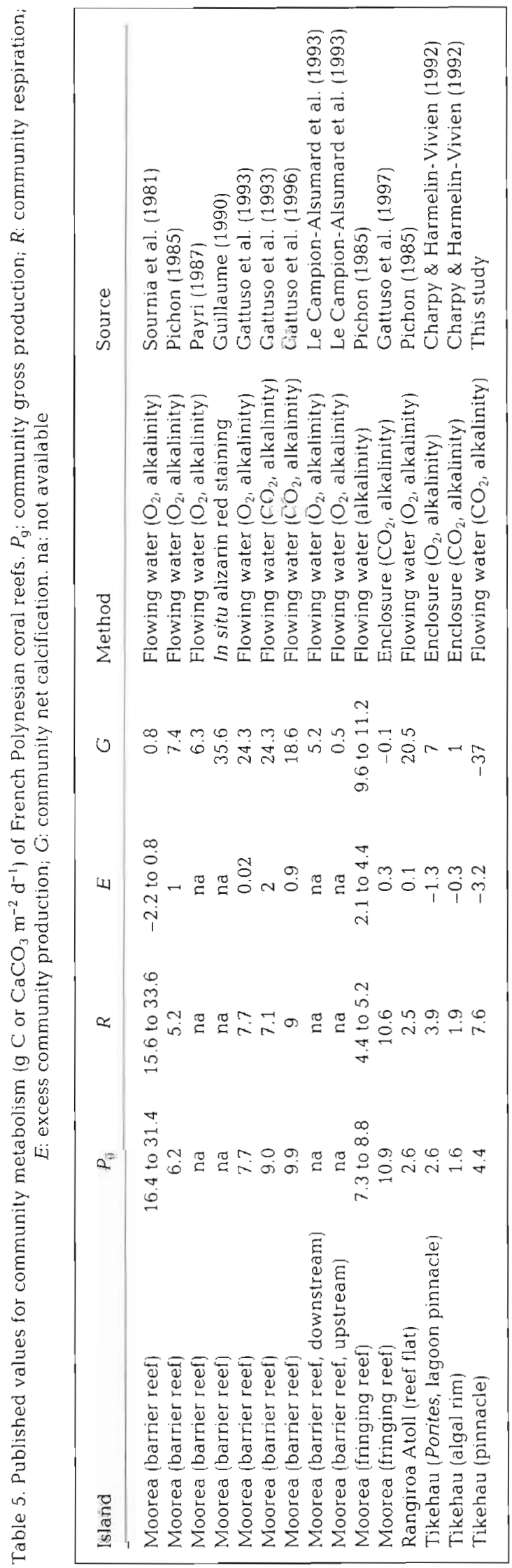


consumed by benthic animals or trapped inside the reef structure. For this reason, the sedimentation rate of POM was not significantly higher close to the pinnacle than far away. The averages of POM concentration and sedimentation rate measured close to and far from the pinnacle were only half as high as the values given by Charpy \& Charpy-Roubaud (1991) for Stn FA in 1986-1987. However, even at the same station, the range of the sedimentation rate measured on 14 occasions was very large $\left(0.1\right.$ to $\left.1.0 \mathrm{~g} \mathrm{C} \mathrm{m}^{-2} \mathrm{~d}^{-1}\right)$.

\section{CONCLUSION}

Heterotrophic processes dominated autotrophic processes at the time of measurement. The influence of coral reef pinnacles on lagoonal water is very low during normal conditions because a large part of the organic matter trapped by the patch reef is respired to sustain the heterotrophic system. However, during storm events, a part of the organic matter of the patch reef would be exported to overlying water and would enrich surrounding sediments.

Acknowledgements. This work is a part of the ORSTOM CYEL program. We thank J.-P. Gattuso for reviewing the draft and anonymous referees for helpfu] comments.

\section{LITERATURE CITED}

Almgren T, Dyrssen D, Strandberg M (1975) Determination of $\mathrm{pH}$ on the moles per $\mathrm{kg}$ seawater scale $\left(\mathrm{M}_{\mathrm{w}}\right)$. Deep-Sea Res 22:635-646

Andrew JC, Muller F (1983) Space time variability of nutrients in a lagoonal patch reef. Limnol Oceanogr 28 $215-227$

Barnes DJ (1983) Profiling coral reef productivity and calcification using $\mathrm{pH}$ and oxygen electrodes. J Exp Mar Biol Ecol 66:149-161

Barnes DJ, Lazar B (1993) Metabolic performance of a shallow reef patch reef near Eliat on the Red Sea. J Exp Mar Biol Ecol 174(1):1-13

Charpy L (1985) Distribution and composition of particulate organic matter in the lagoon of Tikehau (Tuamotu archipelago, French Polynesia). Proc 5th Int Coral Reef Congr 3:353-357

Charpy L, Charpy-Roubaud C (1991) Particulate organic matter fluxes in a Tuamotu Atoll lagoon (French Polynesia). Mar Ecol Prog Ser 71:53-63

Charpy L, Harmelin-Vivien M (1992) Preliminary results on production and calcification of coral reefs communities of Tikehau atoll. Notes Doc Océanogr Tahiti 44:1-20

Charpy-Roubaud C. Charpy L, Cremoux JL (1990) Nutrient budget of the lagoonal waters in an open central South Pacific atoll (Tikehau, Tuamotu, French Polynesia). Mar Biol 107:67-73

Charpy-Roubaud C, Charpy L, Sarazin G (1996) Diffusional nutrient fluxes at the sediment-water interface and organic matter mineralization in an atoll lagoon (Tikehau, Tuamotu Archipelago, French Polynesia). Mar Ecol Prog Ser 132:181-190
Charpy-Roubaud C, Charpy L, Larkum AW (1997) Contribution of $\mathrm{N}_{2}$ fixation to $\mathrm{N}$ productivity of the lagoon of Tikehau. Proc 8th Int Coral Reef Symp 1:803-808

Chisholm JRM, Gattuso JP (1991) Validation of the alkalinity anomaly technique for investigating calcification and photosynthesis in coral reef communities. Limnol Oceanogr 36: $1232-1239$

Crossland CJ, Hatcher BG, Smith SV (1991) Role of coral reefs in global ocean production. Coral Reefs 10:55-64

Eakin CM (1996) Where have all carbonates gone? A model of comparison of calcium carbonate budgets before and after the 1982-1983 El Niño at Uva Island in the eastern Pacific. Coral Reefs 15:109-119

Faure G, Laboute P (1984) Formations récifales: I. Définition des unités récifales et distribution des principaux peuplements de Sclératinaires. Notes Doc Océanogr Tahiti 22: $108-136$

Gattuso JP, Pichon M, Delesalle B, Frankignoulle M (1993) Community metabolism and air-sea $\mathrm{CO}_{2}$ fluxes in coral reef ecosystem (Moorea, French-Polynesia). Mar Ecol Prog Ser 96:259-267

Gattuso JP, Pichon M, Delesalle B, Canon C, Frankignoulle M (1996) Carbon fluxes in coral reefs. I. Lagrangian measurement of community metabolism and resulting air-sea $\mathrm{CO}_{2}$ disequilibrum. Mar Ecol Prog Ser 145:109-121

Gattuso JP, Payri C, Pichon M, Delesalle B, Frankignoulle M (1997) Primary production, calcification, and air-sea $\mathrm{CO}_{2}$ fluxes of a macroalgal-dominated coral reef community (Moorea, French Polynesia). J Phycol 33:729-738

Gordon DC Jr, Sutcliffe WH Jr (1973) A new dry combustion method for the simultaneous determination of total organic carbon and nitrogen in sea water. Mar Chem 1:231-244

Guillaume (1990) Growth and calcium carbonate production of massive Porites (barrier reef flat of French Polynesia). Proc ISRS Congr, Nouméa, p 87-90

Harmelin-Vivien M (1985) Atoll de Tikehau, Archipel des Tuamotu. Proc 5th Int Coral Reef Congr 1:211-268

Hatcher BG (1990) Coral reef primary productivity: a hierarchy of pattern and process. Trends Ecol Evol 5:149-155

Holm-Hansen O, Booth CR (1966) The measurement of adenosine triphosphate in the ocean and its ecological significance. Limnol Oceanogr 11:510-519

Hutchings PA (1986) Biological destruction of coral reefs. A review. Coral Reefs 4:239-252

Kinsey DW (1983) Standard performances in coral reef primary production and carbon turnover. In: Barnes DJ (ed) Perspectives on coral reefs. Australian Inst Mar Science, Townsville, p 209-220

Kinsey DW (1985) Metabolism, calcification and carbon production. I. System level studies. Proc 5th Int Coral Reef Congr 4:505-526

Le Bris S, Le Campion-Alsumard T, Romano JC (1998) Composition et biomasse du feutrage algal épilithe et endolithe soumis a différentes intensités de bioerosion en milieu récifal de Polynésie française. Oceanol Acta (in press)

Le Campion-Alsumard T, Romano JC, Peyrot-Clausade M, Le Campion J, Paul R (1993) Influence of some coral reef communities on the calcium carbonate budget of Tiahura reef (Moorea, French Polynesia). Mar Biol 115:685-693

Maragos JE (1978) Measurement of water volume transport for flow studies. In: Stoddart DR, Johannes RE (eds) Coral reefs: research methods. UNESCO, Paris, p 353-360

Marsh JA, Smith SV (1978) Productivity measurements of coral reefs in flowing water. In: Stoddart DR, Johannes RE (eds) Coral reefs: research methods. UNESCO, Paris, p 361-378

Menzel D, Corwin J (1965) The measurement of total phos- 
phorus in sea water based on the liberation of organically bound fraction by persulfate oxidation. Limnol Oceanogr 10:280-282

Odum HT, Hoskin CM (1958) Comparative studies on the metabolism of marine waters. Publ Inst Mar Sci Univ Texas 5:16-46

Pari N (1998) Les éponges perforantes dans les milieux récifaux actuels et anciens: significations écologiques et paléoécologiques. Thèse, Univ Aix-Marseille I

Pari N, Peyrot-Clausade M, Le Campion-Alsumard T, Hutchings $P$, Chazottes V, Golubic S, Le Campion J, Fontaine MF (1998) Bioerosion of experimental substrates on high islands and on atoll lagoons (French Polynesia) after two years of exposure. Mar Ecol Prog Ser 166:119-130

Payri CE (1987) Variabilité spatiale et temporelle de la communauté des macrophytes des récifs coralliens de Moorea (Polynésie Française). Contribution des algues au métabolisme du carbone de l'écosystème récifal. Thèse, Univ Sciences et Techniques du Languedoc

Perez FF, Fraga F (1987) A precise and rapid analytical procedure for alkalinity determination. Mar Chem 21:169-182

Peyrot-Clausade M (1994) Cryptofaune mobile et macroforeurs des formations récifales: etude quantitative préliminaire. In: Intes A (ed) L'atoll de Tikehau (archipel des Tuamotu, Polynésie Française). Premiers résultats. Notes Doc Océanogr Tahiti 22:137-146

Peyrot-Clausade $M$, Le Campion-Alsumard T, HarmelinVivien M, Romano JC, Chazottes V, Pari N, Le Campion J (1995a) La bioérosion dans le cycle des carbonates: essais de quantification des processus en Polynésie Française. Bull Soc Géol Fr 166:85-94

Peyrot-Clausade $M$, Le Campion-Alsumard T, Hutchings $P$, Le Campion J, Payri C, Fontaine MF (1995b) Initial bio-

Editorial responsibility: Otto Kinne (Editor),

Oldendorf/Luhe, Germany erosion and bioaccretion on experimental substrates in high island and atoll lagoons (French Polynesia). Oceanol Acta 18:531-541

Pichon M (1985) Organic production and calcification in some coral reefs of Polynesia. Proc 5th Int Coral Reef Congr 6: 173-177

Reaka-Kudla ML, Feingold JS, Glynn W (1996) Experimental studies of rapid bioerosion of coral reefs in the Galápagos Islands. Coral Reefs 15:101-107

Risk MJ, Sammarco PW, Edinger EN (1995) Bioerosion in Acropora across the continental shelf of the Great Barrier Reef. Coral Reefs 14:79-86

Sammarco PW (1996) Comments on coral reef regeneration, bioerosion, biogeography, and chemical ecology: future directions. J Exp Mar Biol Ecol 200:135-168

Sammarco PW, Risk MJ (1990) Large-scale patterns in internal bioerosion of Pontes: cross continental shelf trends on the Great Barrier Reef. Mar Ecol Prog Ser 59:145-156

Scott PJB, Risk MJ, Carriquiry JD (1988) El Niño, bioerosion and the survival of east Pacific reefs. Proc 6th Int Coral Reef Symp 2:517-520

Smith SV, Kinsey DW (1978) Calcification and organic carbon metabolism as indicated by carbon dioxide. In: Stoddart DR, Johannes RE (eds) Coral reefs: research methods. UNESCO, Paris, p 469-484

Sourna A, Delesalle B, Ricard M (1981) Premiers bilans de production organique et de calcification d'un récif barrière de la Polynésie Française. Oceanol Acta 4:423-431

Strickland JDH, Parsons TR (1972) A practical handbook of seawater analysis. Bull Fish Res Board Can 167

Yentsch CS, Menzel DW (1963) A method for the determination of phytoplankton chlorophyll and phaeophytin by fluorescence. Deep-Sea Res 10:221-231

Submitted: February 9, 1998; Accepted: July 31, 1998

Proofs received from author(s): October 9, 1998 